\title{
Dinocyst stratigraphy of the Lower Kimmeridge Clay, Westbury, England
}

\author{
HENRIK NØHR-HANSEN
}

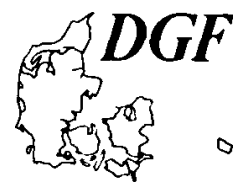

Nøhr-Hansen, H.: Dinocyst stratigraphy of the Lower Kimmeridge Clay, Westbury, England. Bull. geol. Soc. Denmark, vol. 35, pp. 31-51, Copenhagen, October, 29th, 1986.

https://doi.org/10.37570/bgsd-1986-35-05

Dinocyst assemblages from 41 samples collected from a $40 \mathrm{~m}$ section of the Jurassic Lower Kimmeridge Clay in a clay-pit in Westbury, Southern England, are described.

47 dinocyst species, 1 acritarch species and 1 tasmanid species are recorded. A new genus Protobatioladinium and two new species Protobatioladinium westburiensis and Perisseiasphaeridium ingegerdii are proposed. The species Palaeoperidinium crassinervum Deflandre, 1939 is redescribed and emended.

The dinocyst assemblage is confined to the Endoscrinium luridum Zone (Wollam \& Riding, 1983) which correlates with the Cymodoce, Mutabilis and Eudoxus ammonite zones. The Endoscrinium luridum Zone is subdivided into two new dinocyst subzones, Stephanelytron scarburghense and Perisseiasphaeridium pannosum.

Henrik Nøhr-Hansen, Institute of Historical Geology and Palaeontology, Øster Voldgade 10, DK-1350 Co-penhagen K, Denmark. Present address: The Geological Survey of Greenland, Øster Voldgade 10, DK-1350 Copenhagen K, Denmark. November 15th, 1985.

\section{Introduction}

The Kimmeridge clay has its type locality on the Dorset coast of southern England (fig. 1) but in this area the Lower Kimmeridge Clay is poorly exposed. In contrast, an extremely well exposed sequence, perfect for lithostratigraphic and biostratigraphic studies, is available in the clay-pit of Blue Circle Portland Cement, at Westbury, in Wiltshire (Grid Reference ST 882528).

This section includes $40 \mathrm{~m}$ of Lower Kimmeridge Clay which has been divided into three ammonite zones (Birkelund, Callomon, Clausen, Nøhr-Hansen \& Salinas 1983). The section contains $2.5 \mathrm{~m}$ of strata assigned to the upper Cymodoce Zone, $23.3 \mathrm{~m}$ of Mutabilis Zone and $14.5 \mathrm{~m}$ of Eudoxus Zone, all of which belong to the Lower Kimmeridgian sensu anglico. The sediments consist of clay, bituminous clay, oil-shale, septarian nodules and limestone. The beds dip $5^{\circ}$ SSE.

The sequence forms the basis of this dinocyst study, the aim of which is to establish a detailed dinocyst stratigraphy relative to the established ammonite zones. 41 samples from selected beds through the $40 \mathrm{~m}$ sequence form the basis of this study.

\section{Methods}

The samples were prepared using standard palynological techniques. Carbonate and silica was removed by hydrochloric and hydrofluoric acid. The organic residue was briefly oxidized by fuming nitric acid and then washed with a low concentration of potassium hydroxide.

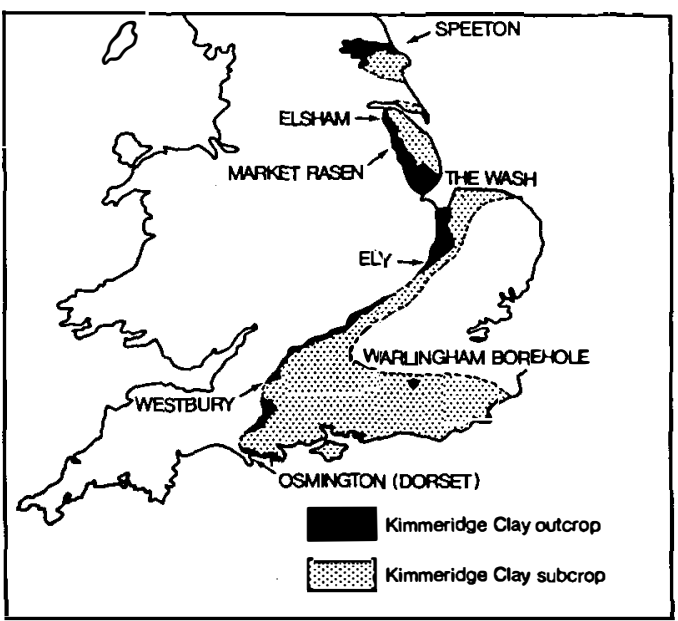

Fig. 1. Map showing the Kimmeridge Clay outcrop and distribution in England. 

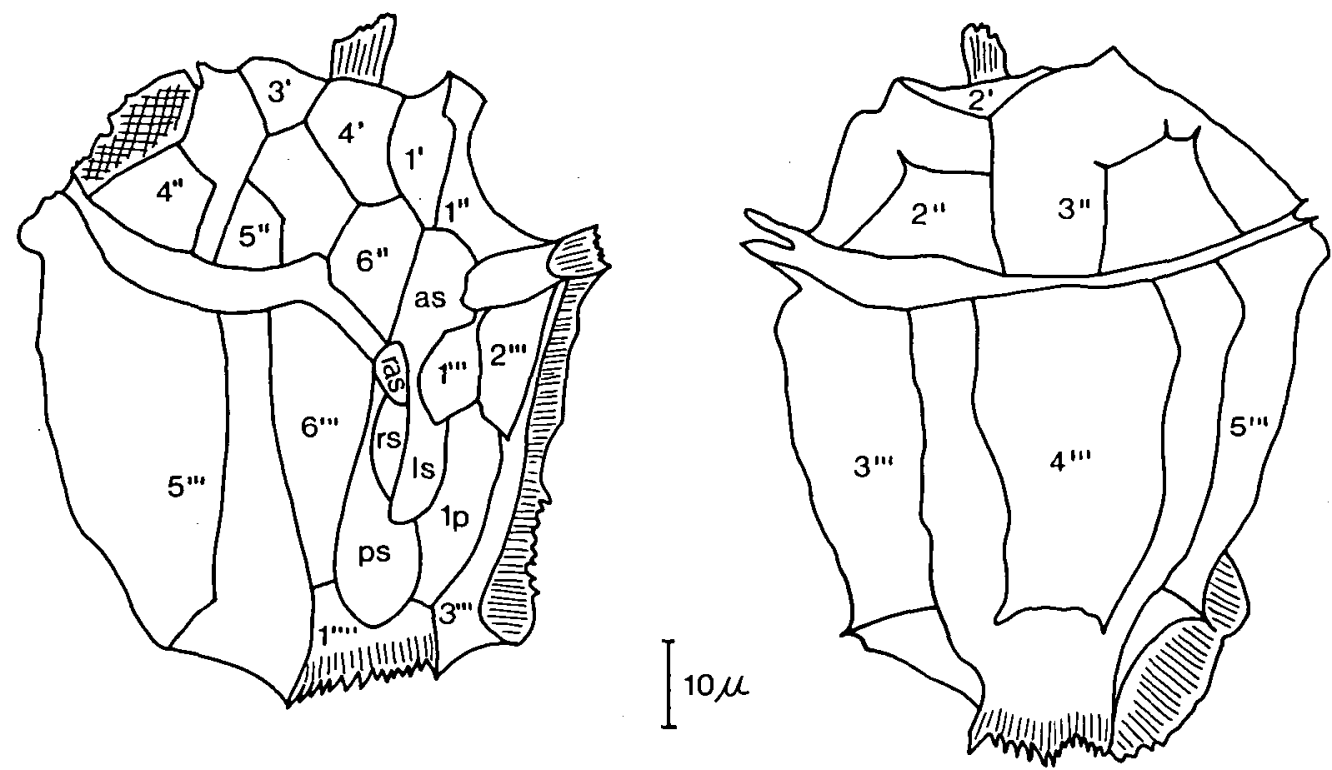

Fig. 3. Cribroperidinium crassinervum emend.

Drawing from photograph (pl. 1, figs. 1 \& 2) with interpretation of the paratabulation pattern, and secondary parasutures. Left ventral view, right dorsal view. MGUH 17008.

a vesiculate internal structure. The wall is $2-3$ my thick, and gives rise to a rigid cyst, which keeps its original shape.

Wall features. Periphragm forms coherent parasutural membranes, which are hollow and tent shaped with a transverse striation and perforate surface (fig. $2 \&$ plate 2, fig. 1). Secondary parasutures with the same construction as the parasutural membranes occur on the pre- and post-cingular paraplates $1^{\prime \prime}-5^{\prime \prime}$ and $2^{\prime \prime \prime}-5^{\prime \prime \prime}$.

Paratabulation. Parasutural membranes indicate the paratabulation but the secondary para-

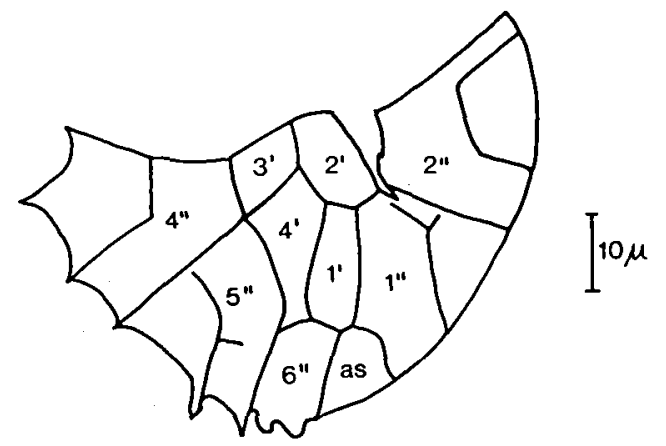

Fig. 4. Cribroperidinium crassinervum emend.

Drawing from photograph (pl. 1, fig. 5). Apical view with interpretation of the paratabulation pattern, and secondary parasutures. MGUH 17010. sutures mask the tabulation pattern. The tabulation formula is: $4^{\prime}, 6^{\prime \prime}, 6 \mathrm{c}(?), 6^{\prime \prime \prime}, 1 \mathrm{p}, 1^{\prime \prime \prime \prime}, 5 \mathrm{~s}$ (as, ras, ls, rs \& ps) (fig. 3) and reflects a gonyaulacoid tabulation pattern. Four apical paraplates are developed. Paraplate $1^{\prime}$ and $4^{\prime}$ are both elongate and placed in continuation of the sulcal field and paraplate $6^{\prime \prime}$, respectively. The paraplates $2^{\prime}$ and $3^{\prime}$ are small. Parasutural membranes of the apical paraplates unite apically to form a blunt apical horn. The apical paraplates contain no secondary parasutures (fig. 4)

Six precingular paraplates are reflected. Para-
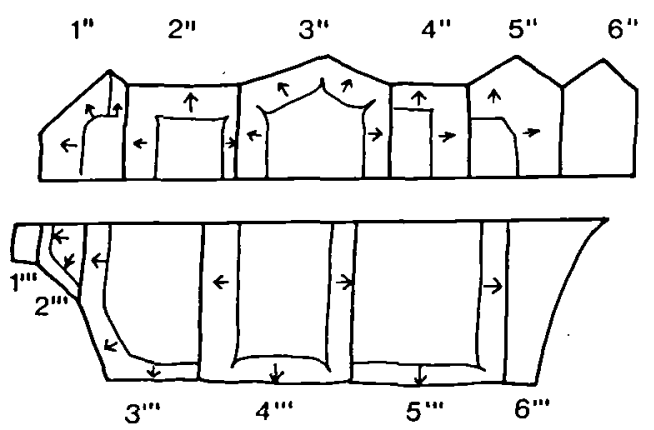

Fig. 5. Cribroperidinium crassinervum emend.

Schematic drawing of the pre- and postcingular paraplate, with interpretation of the secondary parasutures, reflecting the thecal growth lines and directions. 
Scriniodinium Klement 1957.

Scriniodinium inritibilum Riley (in Fisher \& Riley) 1980. (21; pl. 3, fig. 9)

Scriniodinium sp. (22; pl. 3, fig. $10 \&$ pl. 4, fig. 5)

Sentusidinium Sarjeant \& Stover 1978.

Sentusidinium brevispinosum Courtinat \& Gaillard 1980. (23; pl. 5, figs. $3 \&$ 11)

Sentusidinium echinatum (Gitmez \& Sarjeant 1972) Sarjeant \& Stover 1978. (24)

Sentusidinium neophytensum (loannides et al. 1976) Sarjeant \& Stover 1978. (37; pl. 5, fig. 6)

Sentusidinium rioultii (Sarjeant 1968) Sarjeant \& Stover 1978.

(25; pl. 5, figs. 4 \& 12)

Sentusidinium sparsibarbatum Erkmen \& Sarjeant 1980. (32; pl. 5, fig. 5)

Stephanelytron Sarjeant 1961, emend. Stover et al. 1977.

Stephanelytron scarburghense Sarjeant 1961, emend. Stover et al. 1977 . (33; pl. 5, fig. 7)

Systematophora Klement 1960.

Systematophora areolata Klement 1960. (40; pl. 2, fig. 9)

Systematophora penicillata (Ehrenberg 1843) Sarjeant 1980.

(26)

Systematophora sp. (35; pl. 5, figs. 8, 13 \& 14)

Tubotuberella Vozzhennikova 1967.

Tubotuberella apatela Cookson \& Eisenack 1960. (27)

Valensiella Eisenack 1963.

Valensiella ovula (Deflandre 1947) Eisenack 1963. (28; pl. 2, fig. 6)

Incertae sedis

Group Acritarcha Evitt 1963.

Subgroup Acanthomorphitae Downie et al. 1963.

Baltisphaeridium Eisenack 1958, emend. Eisenack 1969.

Baltisphaeridium inusitatum Klement 1960. (41)

Class Prasinophyceae

Family Tasmanaceae Sommer 1956.

Tasmanites Newton 1875.

Tasmanites sp. (46)

\section{Systematics}

Genus Cribroperidinium Neale \& Sarjeant 1962, emend. Davey 1969.

Cribroperidinium crassinervum (Deflandre 1939) emend. Pl. 1, figs. 1-5, pl. 2, fig. 1, text figs. 2-5

Palaeoperidinium crassinervum Deflandre 1939, p. 144, pl. 6, fig. 5

Gonyaulacysta crassinerva (Deflandre 1939) Sarjeant 1967, p. 248-9

Leptodinium crassinervum (Deflandre 1939) Sarjeant 1969 in Davey et al. p. 12

Original diagnosis: (translated from Deflandre 1939) The theca (cyst) is polygonal, divided into two very unequal parts by a profound narrow transversal furrow (paracingulum), which is slightly helicodial.
Epitheca (epicyst) is a double pyramidal-stub; hypotheca (hypocyst) is bowl-shaped slightly tapering towards the antapex. The plate sutures (parasutures) are formed by very salient ribs, and in addition ornamentation exists on some plates. This ornamentation is formed by ribs similar to the ribs which exist on Gonyaulax pachyderma Deflandre.

Tabulation. Very incompletely known.

Dimensions. The length of the holotype is $82 \mathrm{my}$ (epicyst 56 my and hypocyst $36 \mathrm{my}$ ) and the maximum width $69 \mathrm{my}$.

Occurrence. Jurassic, Kimmeridgian; Orbagnoux, France.

It should be noted that Deflandre's original diagnosis is based on a cyst figured up side down compared to the present day orientation. His hypocyst is the epicyst and vice versa.

Emended diagnosis. Proximochorate, elongate, polygonal cysts, divided by a strongly helicoid paracingulum. The outer surface is smooth. The cyst wall appears very spongy; this comes from the internal vesiculate construction of the periphragma. Parasutural membranes indicate a Gonyaulax type of paratabulation. Secondary parasutures, of the same construction as the parasutural membranes, occur on the pre- and postcingular paraplates. The archeopyle is precingular, type $\mathbf{P}$.

\section{Description}

Cyst type. Proximochorate; the parasutural membranes between $10-30 \%$ of the shortest diameter of the central body (cf. Sarjeant 1981).

Shape. The central body is elongate to ellipsoidal. Parasutural membranes form a short, blunt apical horn and an antapical flange. The cyst is wedge-shaped antapically.

Wall relationships. Periphragm and endophragm, are appressed in areas between the parasutural membranes. Surface of the periphragm is smooth with weak transverse striations on the flanks of the membranes. Periphragm has

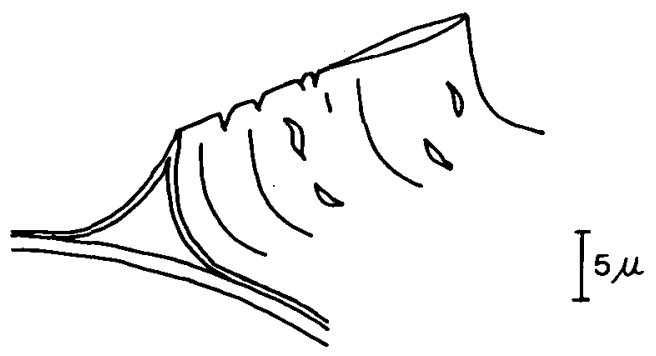

Fig. 2. Cribroperidinium crassinervum emend. Drawing of a hollow tent shaped parasutural membrane. 
plates 1 " -5 " show secondary parasutures, which according to Gocht (1979) are interpreted as morphological imprint of thecal growth lines. Paraplate $3^{\prime \prime}$ reflects thecal growth centre on this plate serie (fig. 5).

The postcingular paraplate series includes likewise six paraplates. Paraplate $1^{\prime \prime \prime}$ is very small and placed half inside the sulcal field. Paraplate $2^{\prime \prime \prime}$ is small and give room for a posterior intercalary paraplate (1p). Paraplates $3^{\prime \prime \prime}, 4^{\prime \prime \prime}$ and $5^{\prime \prime \prime}$ are large (especially $4^{\prime \prime \prime}$ ). Paraplate $6 "$ "' is reduced in proportion to the three previous paraplates. Paraplates $2^{\prime \prime \prime}$ to $5^{\prime \prime \prime}$ have secondary parasutures and paraplate 4 "' reflects the thecal growth centre of this plate series (fig. 5).

Antapex is composed of an antapical paraplate of the Gonyaulax type (Ewitt 1976). Paraplate $1^{\prime \prime \prime \prime}$ is placed on the ventral surface of the cyst, which gives the antapical part of the hypocyst a narrow wedge shape. Paraplate 4 "' is separated from paraplate 1 "'"' by a flange composed of the parasutural membrane.

Archeopyle. This examination of Cribroperidinium crassinervum shows that paraplate 3 " is lost (plate 1, fig. 4), and the archeopyle is of type P.

Paracingulum. Strongly helicoid; paracingulum is displaced 5 to $7 \mathrm{my}$ in the sulcal field (approximately two times the width of the paracingulum). This shape of the paracingulum gives the epicyst and hypocyst nearly equal size on the ventral side, while the hypocyst is roughly twice as large as the epicyst on the dorsal side. Paracingulum is demarcated by two parallel parasutural membranes, which blur the outline of the specific paracingular plates. The outlines of two cingular paraplates are visible (pl. 2, fig. 1) and it is most likely that the paracingulum is composed of six paraplates.

Parasulcus. This area is composed of five clearly demarcated paraplates, an anterior sulcal paraplate (as), a right accessory sulcal paraplate (ras), a right sulcal paraplate (rs), a left sulcal paraplate (ls); and a large tongue shaped posterior sulcal paraplate (ps). In addition, two weakly outlined elongated depressions above each other are visible between ras and 1 "' (pl. 2, fig. 1). These depressions are reflections of the thecas flagellar pores. Parasulcus is very elongate (2/3 of the cyst length) and occupy considerable more area of the hypocyst than of the epicyst.

Dimensions. Overall length 77(81)86 my,

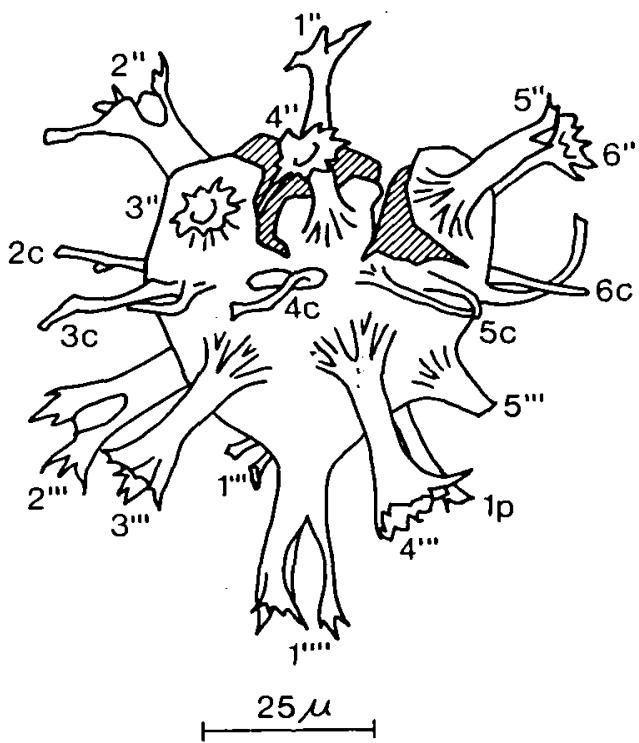

Fig. 6. Drawing of Perisseiasphaeridium ingegerdii sp.nov. From SEM photograph (pl. 4, fig. 8). The processes are interpreted as reflecting a paratabulation pattern. MGUH 17050.

width $50(61) 70 \mathrm{my}$, maximum height of membranes $7(8) 9$ my (nine specimens measured).

Occurrence. $C$. crassinervum is present throughout the Mutabilis Zone and into the lower part of the Eudoxus Zone.

Discussion. This species is transferred to the genus Cribroperidinium Neale \& Sarjeant, 1962 emend. Davey, 1969, on the basis of the following characteristics: proximochorate to proximate cysts of intermediate size, elongate shape, small apical horn, coherent striate parasutural membranes and coherent striate secondary parasutures. Archeopyle P.

Genus Perisseiasphaeridium Davey \& Williams 1966.

Perisseiasphaeridium ingegerdii sp. nov. Pl. 3, fig. 11, pl. 4, figs. 8-9, text fig.6

Origin of name. From Ingegerd, an old Nordic female name. Diagnosis. Skolochorate cysts with a subspherical central body. The cysts posses two types of processes; (1) large, thick, hollow, tubiform processes and (2) slender, massive processes. The processes are intratabular and proximally striate occasionally with "supporting roots". The processes indicate a gonyaulacoid type of 
tabulation pattern. The wall is composed of two layers, endophragm and periphragm. The archeopyle is apical type $\overline{\mathrm{tA}}$.

\section{Description}

Cyst type. Chorate, as the length of the processes exceeds $30 \%$ of the shortest diameter of the central body (cf. Sarjeant 1981). Moreover, the cysts are skolochorate on account of the shape and location of the processes (cf. Sarjeant 1981).

Shape. The central body is subspherical.

Wall relationship. The cyst wall is composed of two layers. An inner layer, endophragm, forms the interior demarcation of the central body. An outer layer, periphragm, has a vesiculate structure. It forms the outer demarcation of the central body and the processes with supporting roots. Periphragm does not show any parasutural structures. Periphragm forms two types of processes; (1) large hollow, tubiform, intratabular processes which are open distally, often weakly aculeate. These processes are proximally striated, as a result of the attachement of the supporting roots. (2) Slender massive, simple processes, which occur in the parasulcal and paracingular areas. The paracingular processes are connected basally, two by two. Distally they are capitate to bifid.

Paratabulation. Paratabulation is indicated by the position and size of the intratabular processes. The pratabulation's formula: 4', 6"', $6 \mathrm{c}(?), 5^{\prime \prime \prime}, 1 \mathrm{p}(?), 1^{\prime \prime \prime \prime}$, ?s.

Archeopyle. The archeopyle is apical of type $\overline{\mathrm{tA}}$. Operculum is simple and attached on some specimens, for example on the holotype (pl. 3, fig. 11), but detached on other specimens (pl. 4, fig. 8).

Paracingulum. The zone of the paracingulum is indicated by six pairs of slender massive processes.

Parasulcus. It has not been possible to count the number of processes.

Holotype. Pl. 3, fig. 11, M16 0,55 H88 As, 40,5-110,2, MGUH 17041.

Type locality. Clay-pit of Blue Circle Portland Cement Company at Westbury, Wiltshire (Grid reference St 882528).

Dimensions. The overall diameter of the holotype is $\mathbf{1 0 4} \mathrm{my}$. The diameter of the central body is $48 \mathrm{my}$ and the maximum length of the processes is $28 \mathrm{my}$. Parameters of 8 specimens are: overall diameter $82(98) 112 \mathrm{my}$, diameter of central body 42(49)60 my, length of processes 20(25)30 my.

Occurrence. Present from the lower part of the Mutabilis Zone to the lower part of the Eudoxus Zone.

Discussion. This species is placed in the genus Perisseiasphaeridium Davey \& Williams 1966, on the basis of the following characteristics: skolochorate cysts with large, subspheroidal central body, distally open, tubiform intratabular processes and simple, slender, paracingular processes.

$P$. ingegerdii sp.nov. differs clearly from $P$. pannosum Davey \& Williams 1966, the processes of which are fenestrate with an irregular distal margin. $P$. ingegerdii sp.nov, is similar to $P$. insolitum Davey 1982, but this species deviates in having processes which are more slender with more regulary aculeate spines.

$P$. ingegerdii sp.nov. differs from Perisseiasphaeridium sp. A. loannides et al. 1976 wich has more slender and often fenestrate processes.

\section{Genus Protobatioladinium gen.nov.}

Diagnosis. The genus includes ovoidal to elongate, proximate cysts with an elongate slender apical horn abruptly rising apically from the cyst. Two small bulges occur antapically. The cysts are thin walled and therefore often folded and strongly compressed. Maximum width occurs in the paracingular region. The archeopyle is compound, type $\overline{\mathrm{t}} \overline{2} \mathrm{I}$, and forms a distinct sulcal notch.

Type species. Protobatioladinium westburiensis sp.nov.

Occurrence. The type species occurs from the top of Cymodoce Zone to the middle of Eudoxus Zone.

Origin of name. The name Protobatioladinium reflects the morphologically strong relationship to the genus Batioladinium. The prefix indicates that Protobatioladinium (Kimmeridgian) occurs stratigraphically earlier than Batioladinium (Volgian? - Lower Cretaceous) and an evolutionary relationship is possible.

Discussion. The genus belongs to the Broomea complex, which includes genera with an ovoidal to elongate shape, an apical horn, none, one or two antapical horns and anterior intercallary, 
apical or apical/intercalary archeopyles. Davey (1982) includes the following genera in the Broomea complex. The archeopyle formula for each genus is given in brackets.

Broomea Cookson \& Eisenack 1958 (2I)

Batioladinium Brideaux $1975(\mathrm{tA})$

Imbatodinium (Vozzhennikova 1967) Dörhöfer

\& Davies 1980) (tA) or (tA2I)

Gochteodinia Norris 1978 (2I)

Pareodinia Deflandre 1947 (2-3I)

Aprobolocysta Duxbury 1977 (tA)

Kalyptea Cookson \& Eisenack 1960 (1-3I)

Cantulodinium Alberti 1961 (2-3I)

Protobatioladinium gen. nov. differs from Broomea, Gochteodinia, Pareodinia, Aprobolocysta, Kalyptea and Cantulodinium in the possession of two small rounded bulges antapicaly and/or in the possession of a compound intercallary/apical archeopyle.

Protobatioladinium gen. nov. is very similar to Batioladinium Brideaux (1975) in general outline and with respect to the presence of a distinct sulcal notch, but differs in the possesssion of a compound $\overline{\mathrm{t} A} 2 \mathrm{I}$ archeopyle in contrast to a $\overline{\mathrm{tA}}$ type. Protobatioladinium gen. nov. differs from Imbatodinium Vozzhennikova (1967) emend. Dörhöfer \& Davies (1980) in the possession of a distinct sulcal notch in contrast to a distinct dorsal notch. In addition, the shape of the anterior intercalary paraplates involved in the archeopyle formation in each genus is very different.

Similarly, Protobatioladinium gen. nov. differs from Imbatodinium Vozzhennikova (1967) emend. Mehrotra \& Sarjeant (1984) in the possession of a distinct sulcal notch. Mehrotra \& Sarjeant illustrate only dorsal notches on all specimens of 1 . fractum Mehrotra \& Sarjeant (fig. 1 a-e Plate 1 figs. 1-7 \& Plate 2 figs. 1-7) which demonstrate all possible variations of plate combinations in the compound archeopyle comprising precingular, anterior intercalary and apical paraplates. Davey (1982) and Evitt (1985) are followed in their retention of the genus Batioladinium Brideaux 1975 because the present author is not convinced that all the species which Dörhöfer \& Davies (1980) and later Mehrotra \& Sarjeant (1984) transferred to the genus Imbatodinium have a compound archeopyle of type $\overline{\mathrm{tA}} 2 \mathrm{I}$. For example, Dörhöfer \& Davies do not prove or illustrate that the type species of Batioladinium,
B. jaergeri (Alberti) Brideaux, has an archeopyle of the Imbatodinium type.

Mehrotra \& Sarjeant agree with the conclusions of Dörhöfer \& Davis concerning the genus Batioladinium and transfer, in addlition, B. pomum Davey (1982) and $B$. radiculatum Davey (1982) into the genus Imbatodinium. This transference is based only on interpretation of the illustrations of Davey (1982).

Protobatioladinium could be a transitional form berween genera with an intercalary archeopyle, for example Pareodinia and genera with an apical archeopyle, for example, Batioladinium. I belive that the above-mentioned rejection of the genus Batioladinium is based on insufficient data (illustrations) without exact proof that all Batioladinium species have a compound archeopyle ( $\mathrm{t} \overline{\mathrm{A}} 2 \mathrm{I})$.

Protobatioladinium westburiensis sp. nov. indicate the possibility of Batioladinium species possessing a $\overline{\mathrm{tA}}$ archeopyle of a shape very similar to the shape of the $\overline{\mathrm{t}} 2 \mathrm{I}$ archeopyle in the genus $I m$ batodinium.

Protobatioladinium westburiensis sp. nov.

Pl. 3, figs. 5-8, text fig. 7 .

Origin of name. From Westbury, the type locality of the species.

Diagnosis. The species is represented by ovoid proximate cysts with an elongate, slender apical horn abruptly raising from the cyst. A constriction on the apical horn is common. Two antapical horns are indicated by two small rounded bulges.
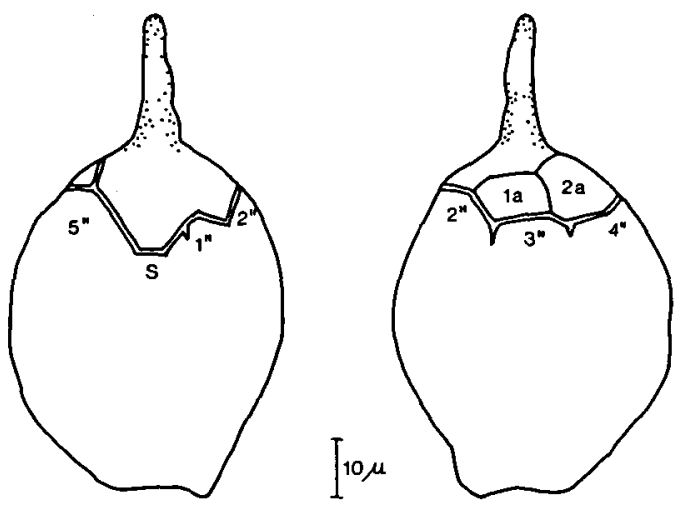

Fig. 7. Protobatioladinium westburiensis sp.nov.

Drawing of the holotype (pl. 3, fig. 5) with interpretation of the shape of the archeopyle as reflecting the paratabulation pattern. Left; ventral view, right; dorsal view. MGUH 17035. 
The cysts are often dorso-ventrally flattened, and widest in the paracingular region. The wall is thin and without any internal structure except vesiculae in the apical horn. The surfaces of the cysts are psilate without any ornamention. The archeopyle sutures reflect a distinct sulcal notch. The archeopyle is compound; type $\overline{\mathrm{tA}} 2 \mathrm{I}$.

\section{Description}

Cyst type. The cyst is proximate with a single wall-layer and no surface ornamentation.

Shape. The cyst is ovoid with a prominent apical horn ( $1 / 4$ to $1 / 3$ of the overall length). The horn is slender, weakly tapering and rises abruptly from the cyst; it is hollow and often has a constriction (fig. 7). Two small rounded bulges occur antapically. These bulges do not exceed $1 / 15$ of the overall length. The cyst is often dorsoventral compressed and folded.

Wall relationships. The wall is apparently composed of one layer; the autophragm. The surface is psilate, smooth without any granula. The wall forming the apical horn is about 1 my thick; it is vesiculate, but otherwise without internal structures.

Paratabulation. Paratabulation is only indicated by archeopyle sutures. The apical demarcation of six precingular paraplates is visilble. On the basis of their shape these paraplates are interpreted as paraplate 1 " to $5^{\prime \prime}$ and one anterior sulcal paraplate, probably as.

On the dorsal side of the cysts the archeopyle sutures completely demarcate two paraplates. These are located right above the precingular paraplate series, and are interpreted as two anterior intercalary paraplates, respectively $1 \mathrm{a}$ and $2 \mathrm{a}$ (fig. 7)

Archeopyle. The archeopyle is formed of three opercular pieces. One piece confines the apical paraplate series and two pieces confine an intercallary paraplate each.

Although the archeopyle sutures are very distinct (pl. 3, fig. 5), and the operculum should be easily lost, all observed specimens have their operculum in situ. A possible explanation is that the wall is double layered and that the visible archeopyle suture is confined to one of these layers only. The other wall layer is then able to retain the operculum attached in situ.
Holotype. Pl. 3, fig. 5, M11 0.20, H76 As, 45,0-128,1, MGUH 17035.

Type locality. Clay-pit of Blue Circle Portland Cement Company at Westbury, Wiltshire (Grid reference ST 882582), England.

Dimensions. The total length of the holotype is $80 \mathrm{my}$, width is $46 \mathrm{my}$. The length of the apical horn is 23 my. Parameters of 7 complete specimens are: total length $67(74) 80$ my, width $34(40) 46 \mathrm{my}$, length of apical horn 20(22) $26 \mathrm{my}$.

Occurrence. Present from the top of the $C y$ modoce Zone to the middle of the Eudoxus Zone.

\section{Dinocyst biostratigraphy}

The 41 samples collected through the measured sequence at Westbury have yielded 47 dinocyst species, 1 acritarch species and 1 tasmanid species. All 49 species are listed alphabetically (see list of species and their stratigraphic occurrence is shown in fig. 9.

In recent years several dinocyst range charts covering the three Lower Kimmeridgian ammonite zones (Cymodoce, Mutabilis and Eudoxus) have been published. Gitmez \& Sarjeant (1972) described microplankton covering the interval from the Baylei Zone (lowest Kimmeridgian) to the Pallasioides Zone (Upper Kimmeridgian) based on samples from England, Scotland and France. Some corrections to this work were published by Riley \& Sarjeant (1977). Lam \& Porter (1977) described palynomorphs covering the interval from Lias to Kimmeridgian based on samples from NE Scotland. Willliams (1977) established a dinocyst range chart covering the interval from Trias to Tertiary. His dinocyst zonation of the Kimmeridgian were based on data from Gitmez \& Sarjeant (1972). Raynaud (1978) described Callovian to Portlandian dinocysts from samples from North Europe. Sarjeant (1979) established dinocyst zonation covering the interval from Middle to Upper Jurassic based on worldwide data, exclusive North America.

Fisher \& Riley (1980) established 7 dinocyst zones around the Jurassic/Cretaceous boundary based on data from the boreal area, these zones were not correlated with ammonite zones. Wollam \& Riding (1983) proposed a dinocyst zonation covering all the English Jurassic. 


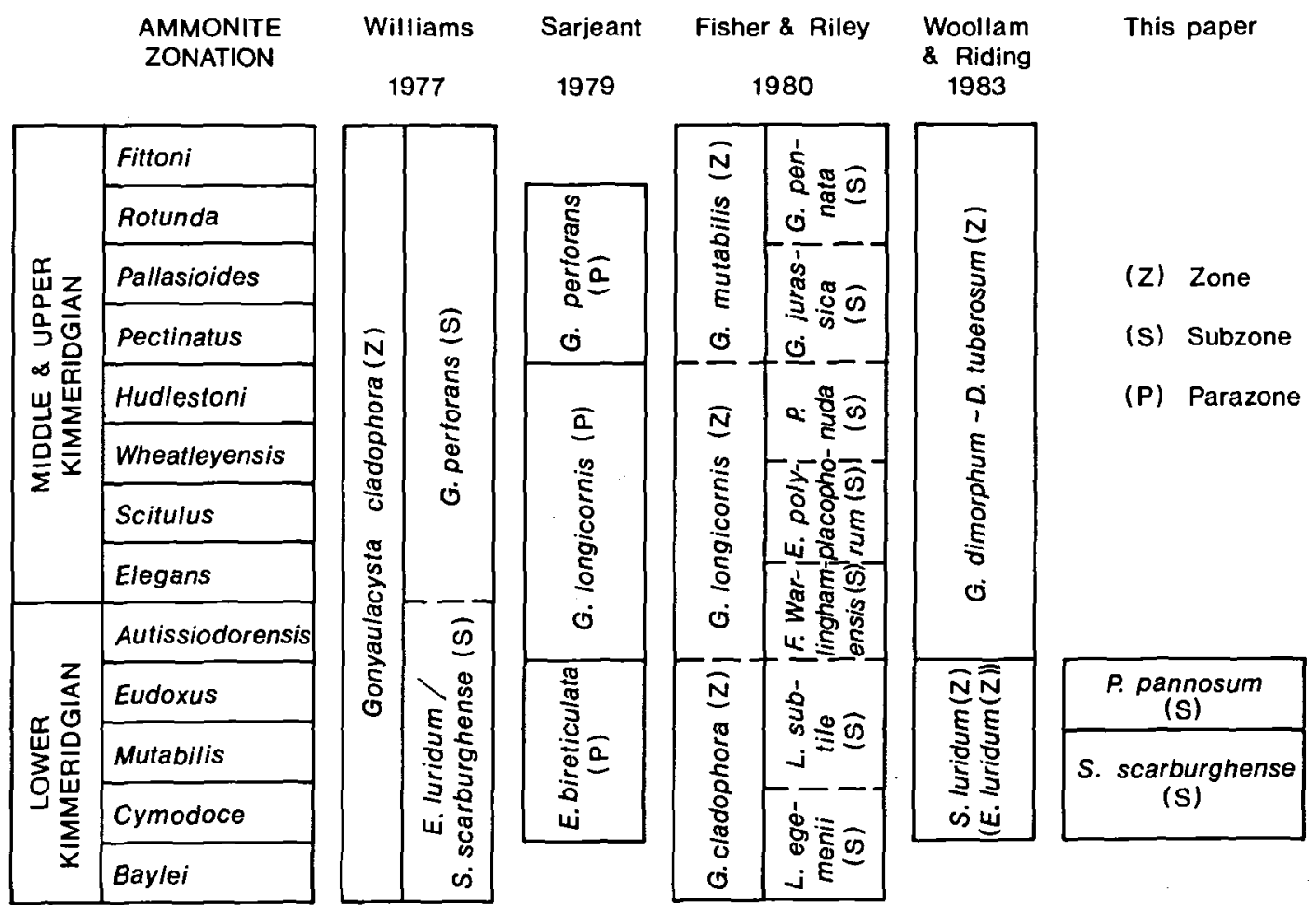

Fig. 8. Correllation of dinocyst and ammonite zonation in the Kimmeridgian sensu anglico.

Williams (1977) defined the Gonyaulacysta cladophora Zone (fig. 8) (now the Hystrichogonyaulax cladophora Zone). This zone covers the entire Kimmeridgian and is subdivided in two subzones: the Gonyaulacysta perforans Subzone, corresponding to Middle and Upper Kimmeridgian, and the Endoscrinium luridum/Stephanelytron scarburghense Subzone, corresponding to Lower Kimmeridgian. The latter is defined by the common last occurrences of $E$. luridum and $S$. scarburghense, in the lower part of the $H$. cladophora Zone.

Sarjeant (1979) proposed the Epiplosphaera bireticulata Parazone, corresponding to the ammonite zones Cymodoce, Mutabilis and Eudoxus (fig. 8). The parazone is defined by the stratigraphical occurrence of $E$. areolata. E. bireticulata and $E$. reticulospinosa, but the three species are not frequent. In this parazone Dingodinium tuberosus and Scriniodinium playfordi have their first occurrence, and the occurrence of the mainly Oxfordian species Endoscrinium luridum fades out.

In 1980 Fisher \& Riley defined a Gonyaula- cysta cladophora Zone, corresponding to the Lower Kimmeridgian only (fig. 8). This zone is subdivided into two subzones. In the lowest one, Leptodinium egeminii Subzone, Nannoceratopsis pellucida, Scriniodinium crystallium, $S$. galeritum and Gonyaulacysta eisenacki have their last occurrence. Glossodinium dimorphum, Pareodinia antennata and Leptodinium egemenii have their first occurrence in this subzone. In the upper Leptodinium subtile Subzone, the index species L. subtile, Endoscrinium luridum, Epiplosphaera areolata and $E$. bireticulata have their highest occurrences.

Woollam \& Riding (1983) established the Scriniodinium luridum Zone (now the Endoscrinium luridum Zone) which correlates with the three ammonite zones Cymodoce, Mutabilis and Eudoxus and with the earlier E. bireticulata Parazone of Sarjeant (1979). The E.luridum Zone is defined as the interval between the last occurrence of Scriniodinium crystallium and the last occurrence of $E$. luridum. The genera Leptodinium, Cribroperidinium and Occisucysta are very abundant in this zone and the species Hystri- 


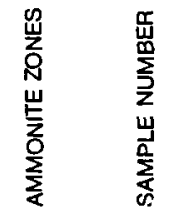

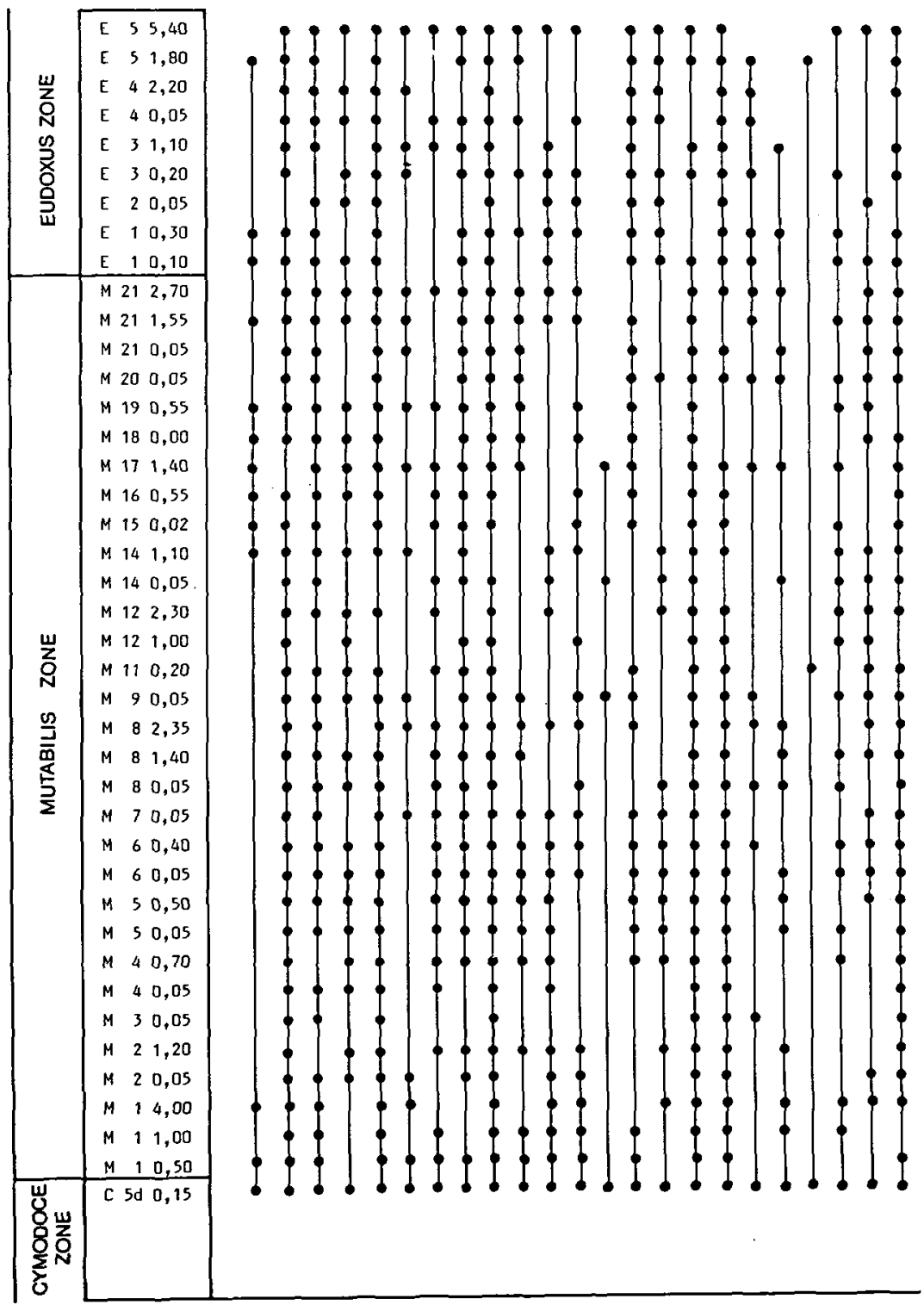

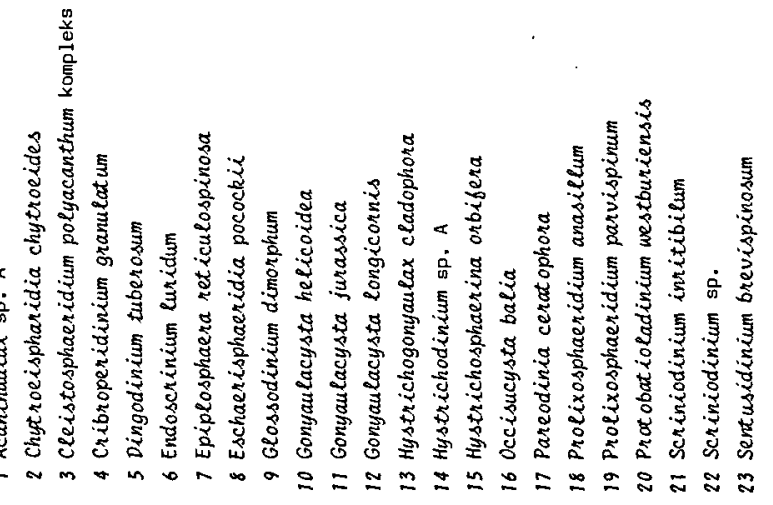


Fig. 9. Distribution of dinocysts in the Lower Kimmeridge clay from Westbury clay-pit. Sample numbers correlate with the bed numbers used in Birkelund et al. 1983 (M 21 1,55 indicates 1,55 m above base of bed 21 in the Mutabilis Zone).
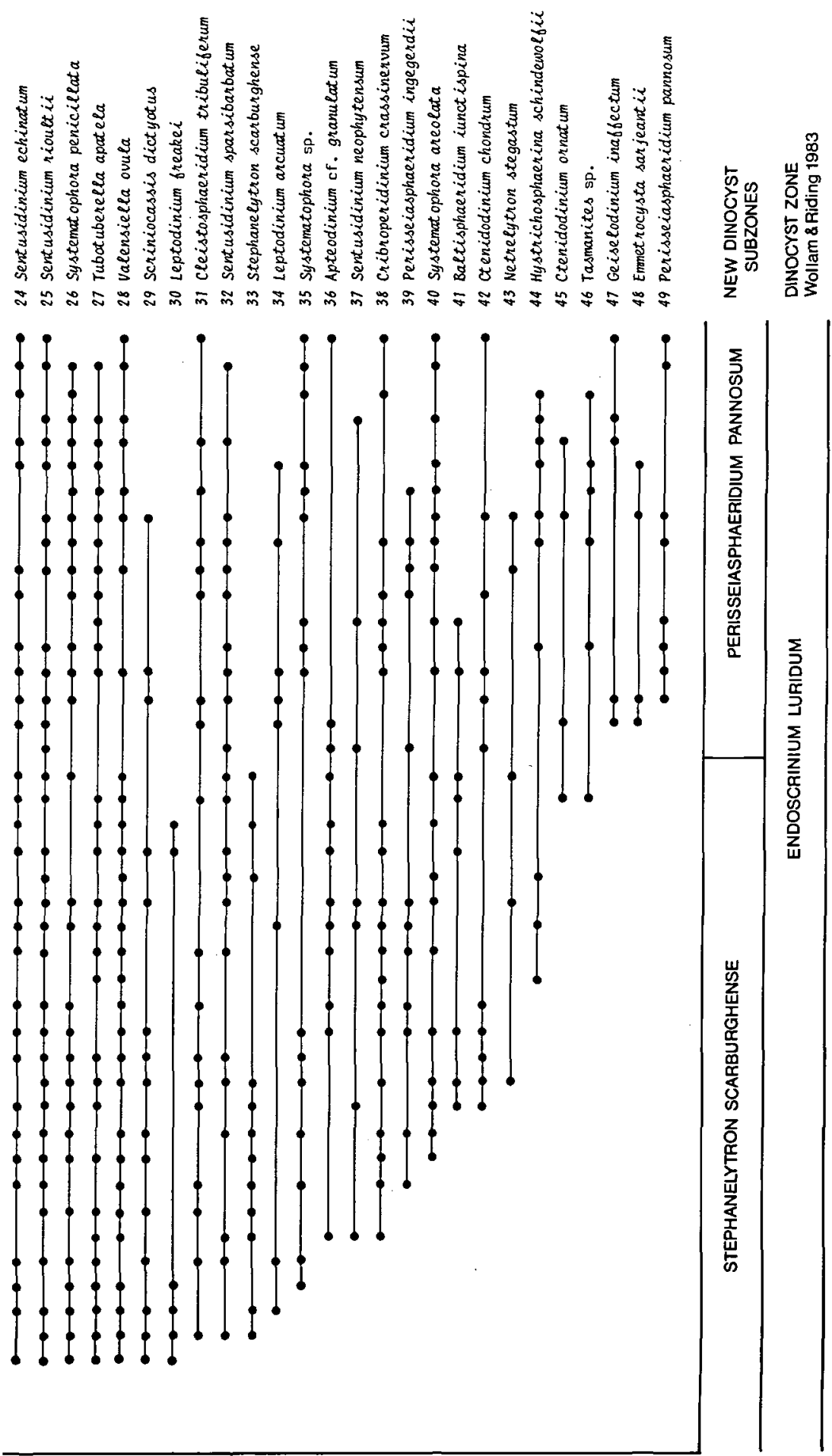
Plate 1.

Figs. 1-5. Cribroperidinium crassinervum MGUH 17008-17010

Fig. 1. Exterior ventral view.

Fig. 2. Interior dorsal view showing secondary parasutures on plate 4 "'.

Fig. 3. Exterior ventral view.

Fig. 4. Interior dorsal view showing a $P$ archeopyle.

Fig. 5. Fragment showing the epicystal paraplates minus the operculum paraplate: $3^{\prime \prime}$.

Fig. 6. Cleistosphaeridium tribuliferum MGUH 17011

Fig. 7. Ctenidodinium chondrum MGUH 17012

Fig. 8. Ctenidodinium ornatum MGUH 17013

Fig. 9. Cleistosphaeridium polyacanthum complex MGUH 17014

Fig. 10. Epiplosphaera reticulospinosa MGUH 17015

Fig. 11-13. Geiselodinium inaffectum MGUH 17016-17018

Fig. 14. Gonyaulacysta helicoidea specimen with operculum inside MGUH 17019

Fig. 15. Gonyaulacysta jurassica specimen with operculum inside MGUH 17020

Fig. 16. Apteodinium cf. granulatum specimen with operculum inside MGUH 17021

Fig. 17. Leptodinium freakei MGUH 17022

Fig. 18. Leptodinium arcuatum MGUH 17023

All photographs are $\mathbf{x} 500$ 

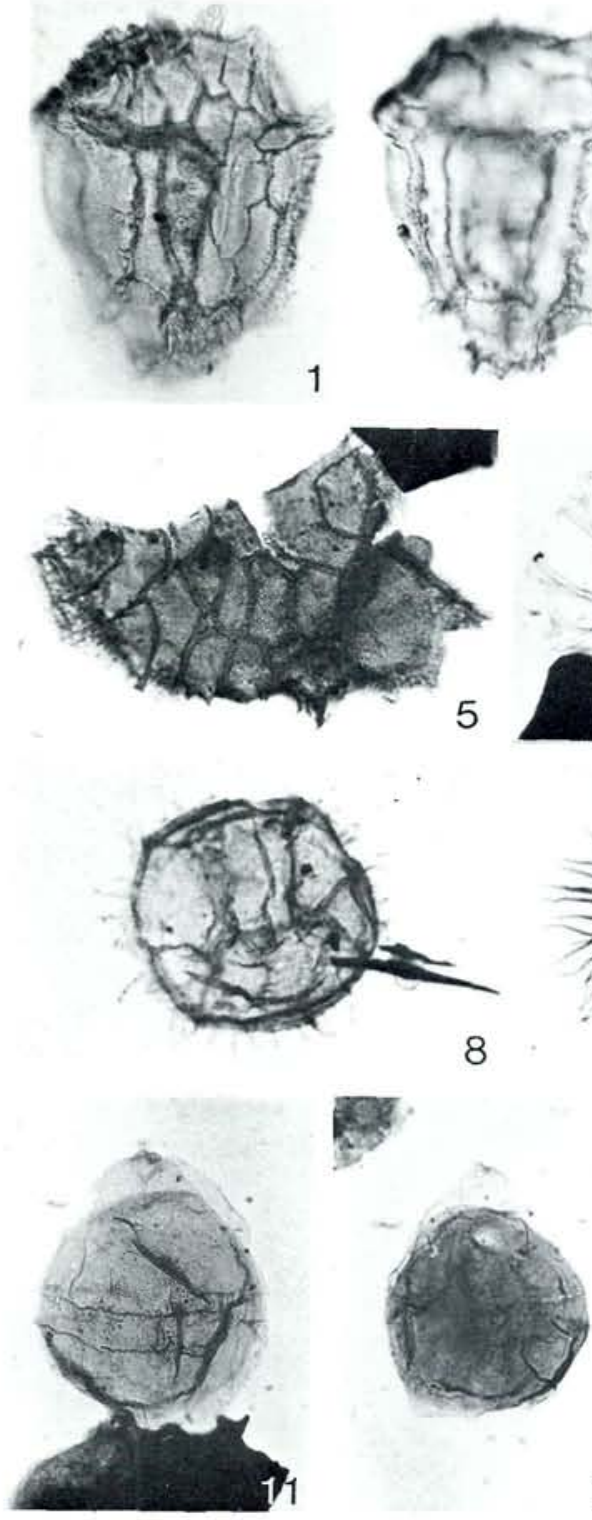

12

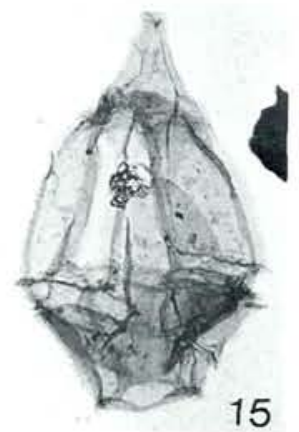

15

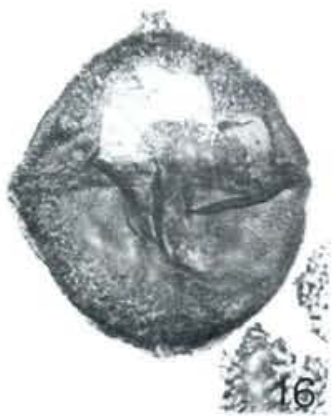

5

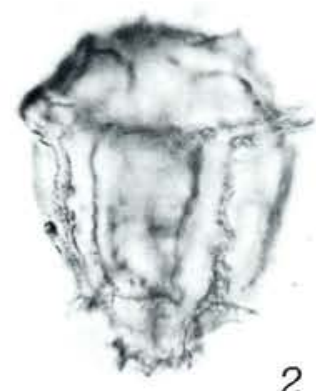

2
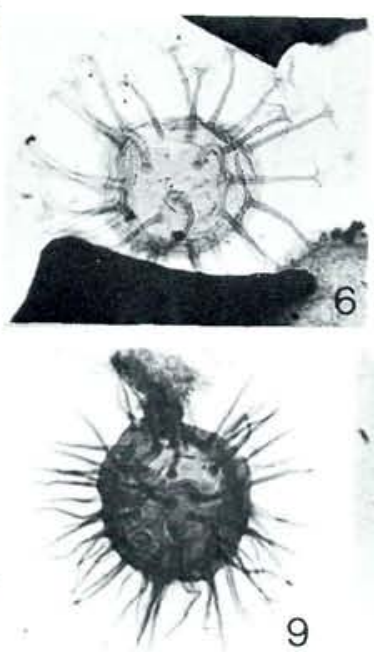
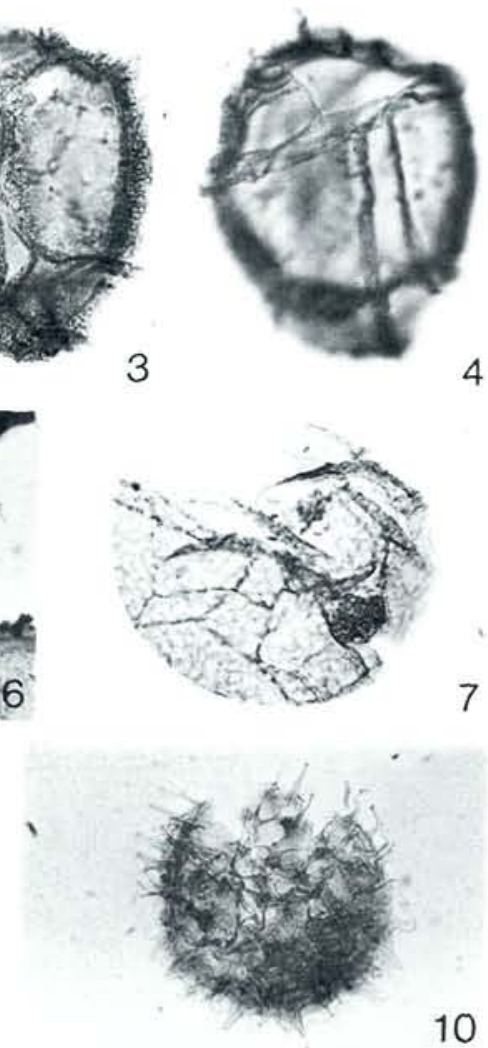

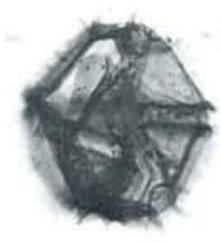

13

14

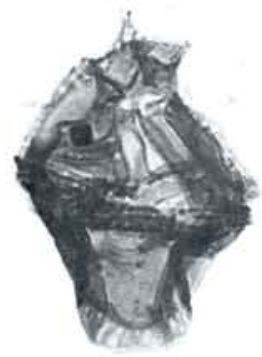

17

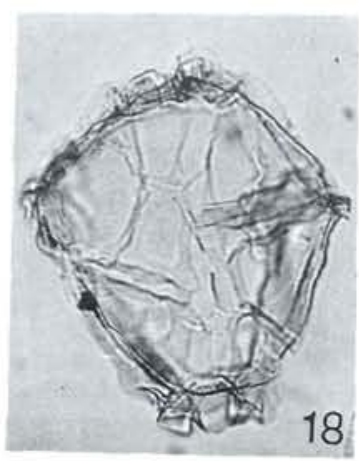


chogonyaulax cladophora and Gonyaulacysta jurassica occur continously.

Sarjeant's (1979) Epiplosphaera bireticulatum Parazone, Fisher \& Riley's (1980) Leptodinium subtile Subzone and Wollam \& Riding's (1983) Endoscrinium luridum Zone, all represent the same stratigraphical time interval. In the present paper use of the E. luridum Zone is preferred, according to Wollam \& Riding's definition, based on very common species.

In the sediments from Westbury all the stratigraphical important species from the $E$. luridum Zone (Wollam \& Riding 1983) are represented and support an assignment to this zone (fig. 9). Diagnostic species are Dingodinium tuberosum (5), Endoscrinium luridum (6), Epiplosphaera reticulospinosa (7), Glossodinium dimorphum (9), Gonyaulacysta jurassica (11), and Occisucysta balia (16), which all occur throughout the sequence. The following stratigraphically important species occur only in part of the sequence: Hystrichogonyaulax cladophora (13), Scriniocassis dictyotus (29), Stephanelytron scarburghense (33), Leptodinium arcuatum (34), and Systematophora areolata (40).

Furthermore, the ammonite stratigraphy of the Westbury sequence (Birkelund et al. 1983) confirms that the dinocyst zone of $E$. luridum correlates with the ammonite zones Cymodoce, Mutabilis and Eudoxus as earlier indicated by Wollam \& Riding (1983).

Most of the recorded dinocyst species occur through the entire sequence. A few important species, however, have limited occurrence, which is regarded as being of stratigraphical importance. These are Stephanelytron scarburghense (33), which has its last occurrence in sample M15 0,02 and Leptodinium freakei (30), which has its last occurrence in sample M14 0,05. Geiselodinium inaffectum (47) has its first occurrence in sample M17 1,40 and Perisseiasphaeridium pannosum (49) has its first occurrence in sample M18 0,00 .

Stover, Sarjeant \& Drugg (1977) wrote that $S$. scarburghense occurs stratigraphically from the Jason Zone, Middle Callovian to the Eudoxus Zone, but is absent in the Mutabilis Zone. A single specimen is recorded from the Eudoxus Zone, and Stover et al. indicated themselves the possibility of a redeposited specimen. The observation by Stover et al. 1977 differs from the present investigation where $S$. scarburghense occurs in the Mutabilis Zone but not in the Eudoxus Zone.

L. freakei is only recorded from the Cordatum Zone, Lower Oxfordian (Sarjeant 1963 and 1979). In the sequence from Westbury $L$. freakei occurs from the upper part of the Cymodoce Zone to the middle of the Mutabilis Zone, $8 \mathrm{~m}$ below the boundary between the Mutabilis and the Eudoxus Zone.

Geiselodinium inaffectum is only previously recorded from the Eudoxus and the Autissiodorensis Zones (Drugg 1978). In Westbury this species has its first occurrence in the Mutabilis Zone, 4,5 $\mathrm{m}$ below the boundary with the Eudoxus Zone. Moreover, this species is recorded in three samples from the Eudoxus Zone.

Plate 2 SEM photographs

Fig. 1. Cribroperidinium crassinervum MGUH 17024 showing ventral side, all the sulcal paraplates and the parasutural membranes with a transvers striation ( $\mathrm{x} 500)$

Fig. 2 \& 3. Epiplosphaera reticulospinosa MGUH 17025 Fig. 2 (x1000) Fig. 3 showing a close-up of the archeopyle suture and the reticulate surface pattern $(\mathrm{x} 2500)$

Fig. 4. Gonyaulacysta helicoidea MGUH 17026 ventral view (x800)

Fig. 5. Leptodinium freakei MGUH 17027 showing paratabulation pattern (x600)

Fig. 6. Valensiella ovula MGUH 17028 (x1000)

Fig. 7 \& 8. Apteodinium cf. granulatum MGUH 17029

Fig. 7 dorsal view showing the archeopyle: $3 P(x 600)$

Fig. 8 close-up showing the wall structure $(x 1500)$

Fig. 9. Systematophora areolata MGUH 17030 operculum attached (x500) 
Perisseiasphaeridium pannosum is reported to have its first occurrence in the Ypresian, Lower Eocene in England (Davey, Downie, Sarjeant \& Williams (1966). Fensome (1979) reported Perisseiasphaeridium cf. $P$. pannosum in one sample from Jameson Land, East Greenland. This sample is dated as Lower Kimmeridgian (Mutabilis to the Eudoxus Zone). Fensome considered that the $P$. pannosum originally described by Davey \& Williams (1966) from Tertiary sediments is a reworked Jurassic species. Piasecki (1980) reported P. pannosum from Milne Land, East Greenland, where it has its first occurrence at the base of the Eudoxus Zone. Gitmez \& Sarjeant (1972) reported specimens of Oligosphaeridium pulcherrimum (Deflandre \& Cookson 1955) from the Bailey Zone (fig. 8) in England and from the $\mathrm{Eu}$ doxus Zone in France (Riley \& Sarjeant 1979). Fensome (1979) considered these specimens to correspond to $P$. cf. $P$. pannosum as Vigran \& Thusu (1976) reported from Lower Kimmeridgian beds at Andøya in Norway.

The above-mentioned observations are supported by the present investigation, where the
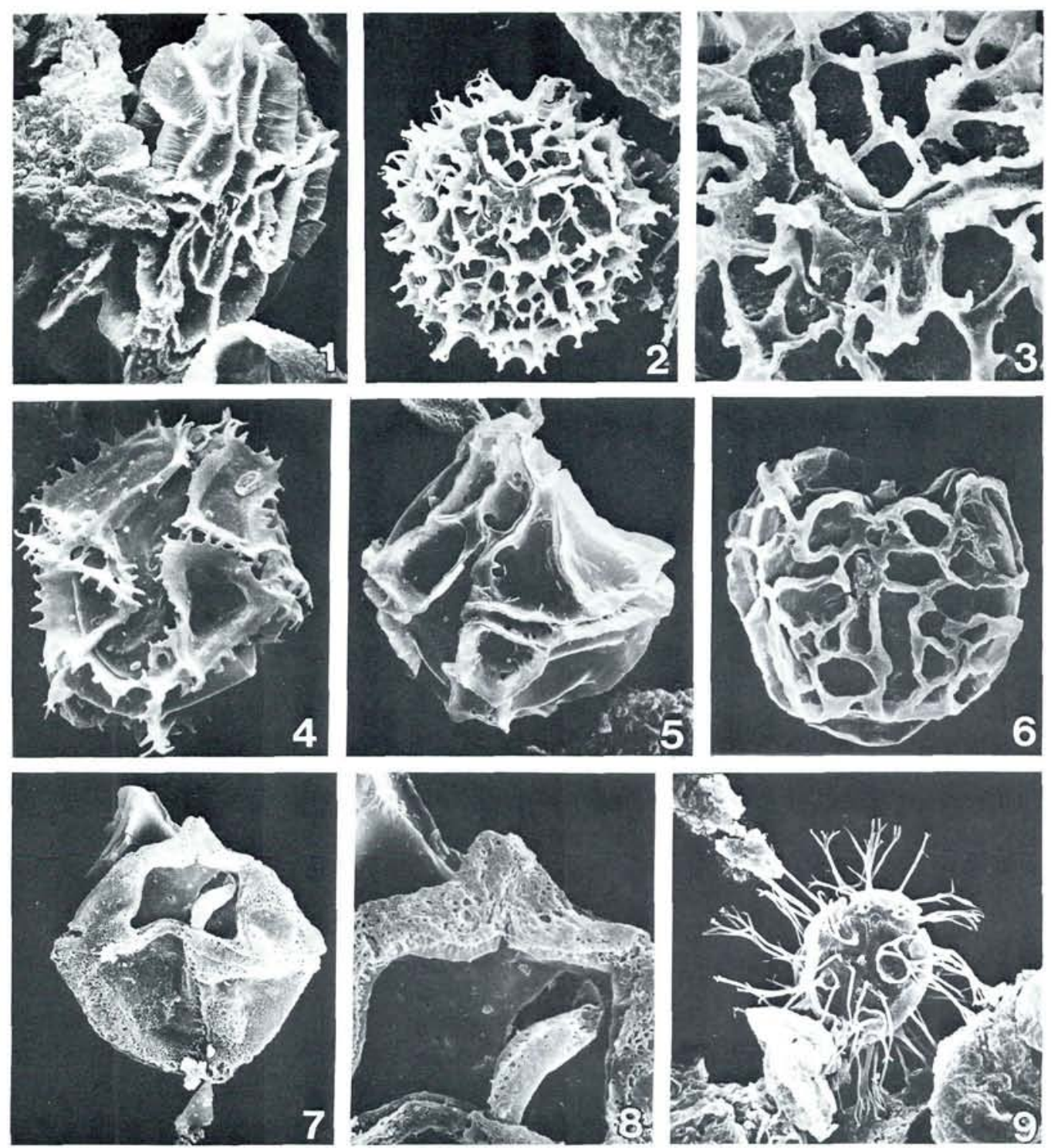
first occurrence of $P$. pannosum is recorded in the uppermost part of the Mutabilis Zone, $4 \mathrm{~m}$ below the boundary of the Eudoxus Zone. Moreover, the species is recorded scattered through the interval of the Eudoxus Zone.

Present observations suggest that the $E$. luridum Zone could be subdivided into two subzones; the Stephanelytron scarburghense Subzone and the Perisseiasphaeridium pannosum Subzone.

The Stephanelytron scarburghense Subzone is defined as the interval from the last occurrence of Scriniodinium crystallium to the last occurrence of Stephanelytron scarburghense. This subzone includes the Cymodoce Zone and the lower and middle part of the Mutabilis Zone.

The Perisseiasphaeridium pannosum Subzone is defined as the interval between the common first occurrence of Perisseiasphaeridium pannosum and Geiselodinium inaffectum and the last occurrence of Scriniodinium luridum. This subzone corresponds to the upper part of the Mutabilis Zone and the entire Euduxus Zone.

In the sequence of Westbury Clay-pit the boundary between the two subzones is situated in the Mutabilis Zone, approximately $6 \mathrm{~m}$ below the boundary to the Eudoxus Zone.

Acknowledgements. I am grateful to Messrs. M. A. Easton and E. D. Knights, General Works Managers, and their colleagues at the Blue Circle Portland Cement Company's Westbury Works for admitting me to their pit, and for their hospitality during two prolonged field visits.
I also thank S. Piasecki, K. Raunsgaard Petersen, and T. Birkelund for discussions and suggestions to improve the manuscript; J. S. Peel improved the English at the manuscript.

J. Lautrup prepared the photographs, B. Sikker Hansen produced the figures; A. T. Bruun and B. Larsen typed the manuscript.

The Geological Institute, University of Copenhagen is thanked for fieldwork grants and permission to use the scanning electron microscope.

\section{Dansk sammendrag}

Fra Westbury i syd England er en $40 \mathrm{~m}$ mægtig Nedre Kimmeridge, Jura, sekvens undersøgt for dinoflagellat cyster.

På baggrund af 47 observerede dinoflagellat arter er Kimmeridge sekvensen henført til Endoscrinium luridum Zonen (Wollam \& Riding 1983) som korrellerer med ammonit zonerne $C y$ modoce, Mutabilis og Eudoxus, hvilket svarer til en tidligere ammonit datering foretaget af Birkelund, Callomon, Clausen, Nøhr-Hansen \& Salinas (1983).

Desuden opdeles dinoflagellat cyst zonen Endoscrinium luridum i to nye subzoner (fig. $8 \circ g$ 9) Stephanelyton scarburghense Subzonen og Perisseiasphaeridium pannosum Subzonen.

Desuden er en ny dinoflagellat slægt beskrevet, Protobatioladinium gen.nov. og dens variation fra slægterne Batioladinium og Imbatodinium er diskuteret. To nye arter Protobatioladinium westburiensis sp.nov. og Perisseiasphaeridium ingegerdii sp.nov. er beskrevet og arten Cribroperidinium crassinervum (Deflandre 1939) emend. er genbeskrevet og redefineret.

\section{References}

Birkelund, T., Callomon, J. H., Clausen, C. K., NøhrHansen, H. \& Salinas, I. 1983: The Lower Kimmeridge Clay at Westbury, Wiltshire, England. Proc. Geol. Ass. 94(4), 289-309.

Brideaux, W. W., 1975: Taxonomic note: redefinition of the Broomea and its relationship to Batioladinium gen. nov. (Cretaceous). Canadian Jour. Botany 53, 1239-43.

Plate 3.

Fig. 1. Occisucysta balia MGUH 17031 showing the archeopyle; 2P

Fig. 2. Prolixosphaeridium parvispinum MGUH 17032

Fig. 3. Prolixosphaeridium anasillum MGUH 17033

Fig. 4. Netrelytron stegastum MGUH 17034

Fig. 5-8. Protobatioladinium westburiensis sp. nov. MGUH 17035-17038 Fig. 5 Holotype showing archeopyle sutures and a constriction on the apical horn.

Fig. 9. Scriniodinium inritibilum MGUH 17039

Fig. 10. Scriniodinium sp. MGUH 17040

Fig. 11. Perisseiasphaeridium ingegerdii sp. nov. MGUH 17041 holotype, operculum attached.

Fig. 12-13. Perisseiaspharidium pannosum MGUH 17042-17043

All photographs $x 500$ 

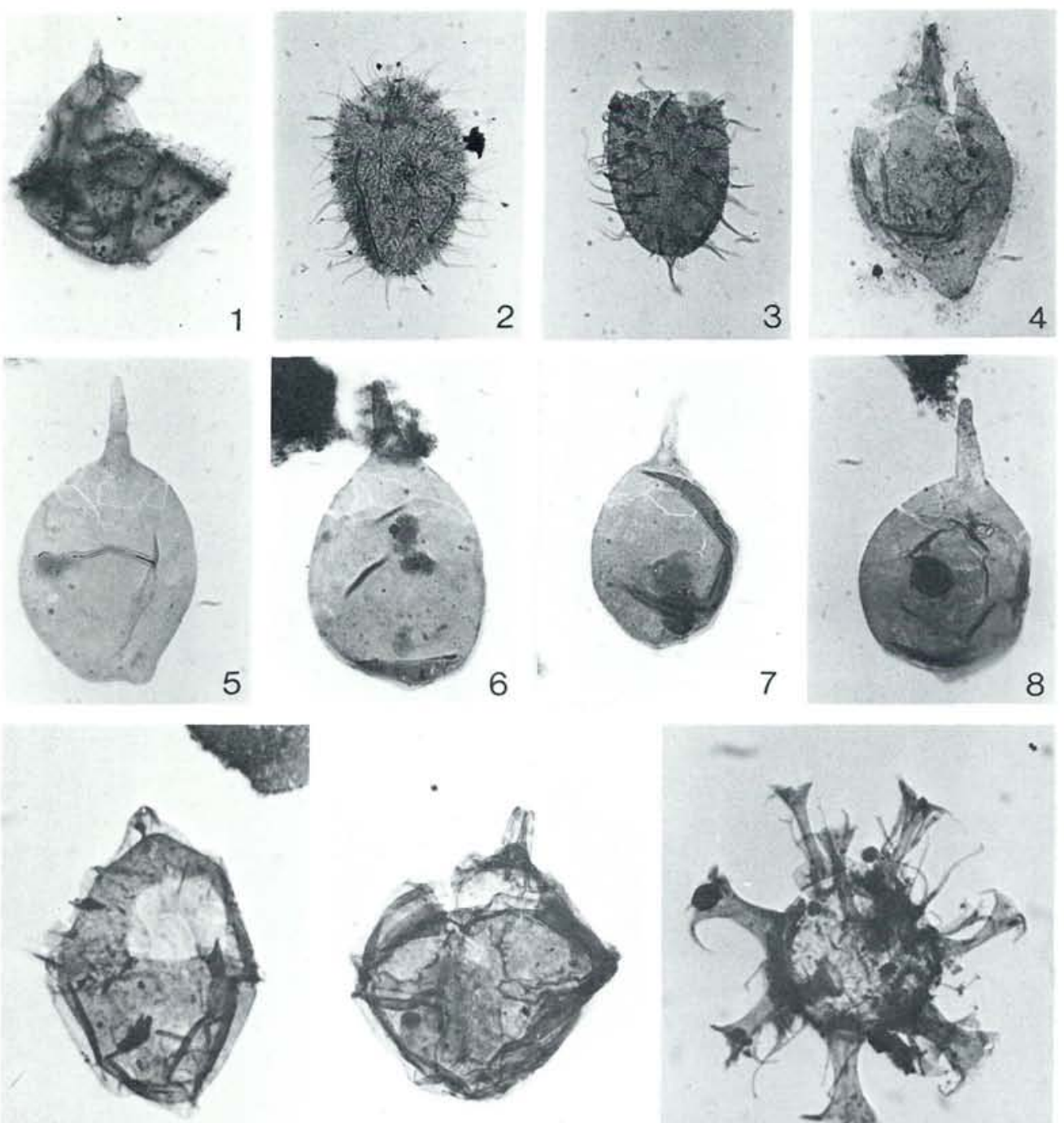

9

10
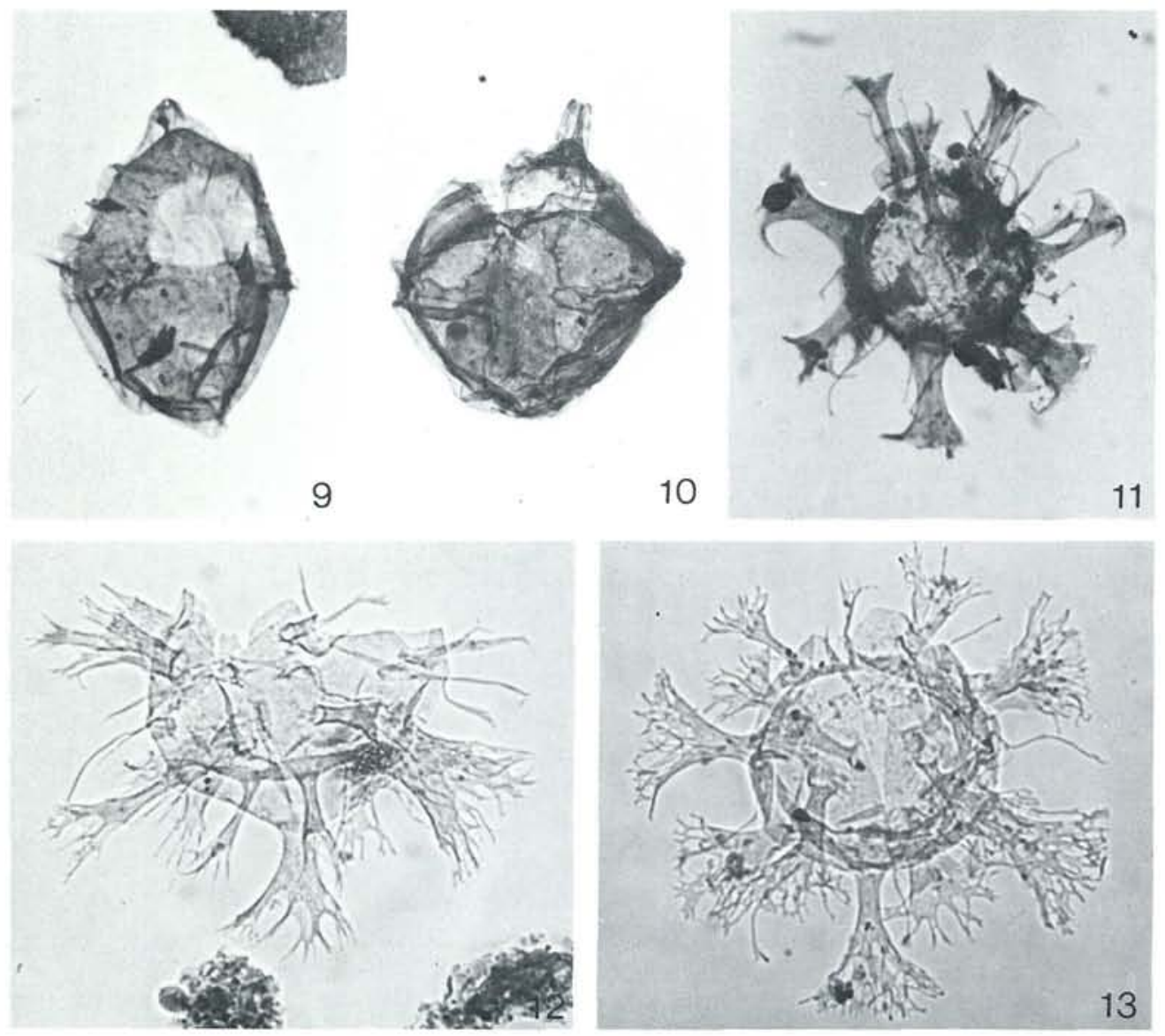
Courtinat, B. \& Gaillard, C. 1980: Les dinoflagelles des calcaires lites de Trept (Oxfordian Superieur) inventaire et repatition comparee a celle de la microfaune benthique. Lyon Fac. Sci. Lab. Geol. 78,1-123.

Davey, R. J., 1982: Dinocyst stratigraphy of the lastest jurassic to Early Cretaceous of the Haldager No. 1 borehole, Denmark. Geol. Surv. Denmark, Ser. B, 6;1-56.

Davey, R. J., Downie, C., Sarjeant, W. A. S. \& Williams, G. L. 1966: Studies on Mesozoic and Cainozoic dinoflagellate cysts. Bull. Br. Mus. (Nat. Hist.) Geol. Supplement 3, 1248.

Deflandre, G. 1939: Sur les Dinoflagelles des schistes bitumineux d'Orbagnoux (Jura). Bull. Soc. franc. Microsc. 8, 141-145.

Drugg, W. S. 1978: Some jurassic dinoflagellate cysts from England, France and Germany. Palaeontographica, Abt. B, 168, 61-79.

Döhöfer, G. \& Davies, E. H. 1980: Evolution of archeopyle and tabulation in rhaetogonyaulacinean dinoflagellate cysts. Royal Ontario Museum. Series: Life sciences miscellaneous publication 1-91.

Erkmen, U. \& Sarjeant, W. A. S. 1980: Dinoflagellate cysts, acritarchs and tasmanitids from the uppermost Callovian of England: With a reconsideration of the "Xanthidium pilosum" problem. Geobios 13, 1; 45-99.

Evitt, W. R. 1985: Sporopollenin dinoflagellate cyst, their morphology and interpretation. AASP, 1-333.

Fensome, R. A. 1979: Dinoflagellate cysts and acritarchs from the Middle and Upper Jurassic of Jameson Land, East Greenland. Bull. Gronlands geol. Unders. 132, 1-98.

Fisher, M. J. \& Riley, L. A. 1980: The stratigraphic distribution of dinoflagellate cysts at the boreal Jurassic - Cretaceous boundary. IV Int. Palynol. Conf., Lucknow (1976-77), 2, 313-329.

Gitmez, G. U. \& Sarjeant, W. A. S. 1972; Dinoflagellate cysts and acritarchs from the Kimmeridgian (Upper Jurassic) of England, Scotland and France. Bull. Br. Mus. (Nat. Hist.) Geol. 21, 5, 171-257.

Lam, K. \& Porter, R. 1977: The distribution of palynomorphs in the Jurassic rocks of the Brora Outlier, NE Scotland. $J l$. Geol. Soc. Lond. 134, 45-55.
Lentin, J. K. \& Williams, G. L. 1981: Index to genera and species. (1981 Edition). Bedford institute of oceanography. Report: Bl-R-81-12, 1-345.

Mehrotra, N. C. \& Sarjeant, W. A. S. 1984: Archeopyle type in the dinoflagellate cyst genus Imbatodinium: some new observations. Micropaleontology 30, 2, 213-222.

Piasecki, S. 1980: Middle to Late Jurassic dinoflagellate cyst stratigraphy from Milne Land and Jameson Land (East Greenland) correlated with ammonite stratigraphy. Unpubl. Thesis, University of Copenhagen.

Raynaud, J. F. 1978: Principaux dinoflagelles caracteristiques du jurassique superieur d'Europe du Nord. Palinologia, num. extraord., 387-405.

Riley, L. A. \& Sarjeant, W. A. S. 1977: Age de quelques assemblages de dinoflagellates et acritarches du Kimmeridgien (Jurassique Superieur) du Boulonnais, Nord de la France. Rev. Micropaleont. 20, 1, 49-52.

Sarjeant, W. A. S., 1963: Two new Jurassic species of Gonyaulax (Dinophyceae). Rev. Micropaleont. 6, 2, 85-88.

Sarjeant, W. A. S. 1979: Middle and Upper Jurassic dinoflagellate cysts: The world excluding America. AASP Contributions Serie 5B, 133-157.

Sarjeant, W. A. S. 1981: Dinoflagellate cyst terminology: A discussion and proposal. Can. J. Bot. 60, 922-945.

Stover, L. E., Sarjeant, W. A. S. \& Drugg, W. S. 1977: The Jurassic dinoflagellate genus Stephanelytron: emendation and discussion. Micropaleontology 3, 330-338.

Vigran, J. O. \& Thusu, B, 1976: Illustrations of Norwegian microfossils. Illustrations and distribution of the Jurassic palynomorphs of Norway. N.T.N.F. Continental Shelf Project 65, 1-58.

Williams, S. 1977: Dinocysts: their classification, biostratigraphy and palaeoecology. In: Ramsay, A. T. S. (ed) Oceanic micropalaentology 2. Academic Press, London. 1231-1235.

Woollam, R. \& Riding, J. B. 1983: Dinoflagellate cyst zonation of the English Jurassic. Rep. Inst. Geol. Sci. 83(2). 1-41.

Plate 4 SEM photographs

Figs. 1-4. Occisucysta balia MGUH 17044-17046

Fig. 1 (x800), Fig. 2 close-up showing the apical horn (x2500), Fig. 3 showing the archeopyle: $2 \mathrm{P}$ (x800), Fig. 4 Antapical view (x1100)

Fig. 5. Scriniodinium sp. MGUH 17047 (x800)

Fig. 6. Prolixosphaeridium anasillum MGUH 17048 (x600)

Fig. 7. Prolixosphaeridium parvispinum MGUH 17049 (x800)

Fig. 8 \& 9. Perisseiasphaeridium ingegerdii sp. nov. MGUH 17050 Fig. 8 (x600) Fig. 9 close-up showing process with supporting roots $(\mathrm{x} 2500)$ 

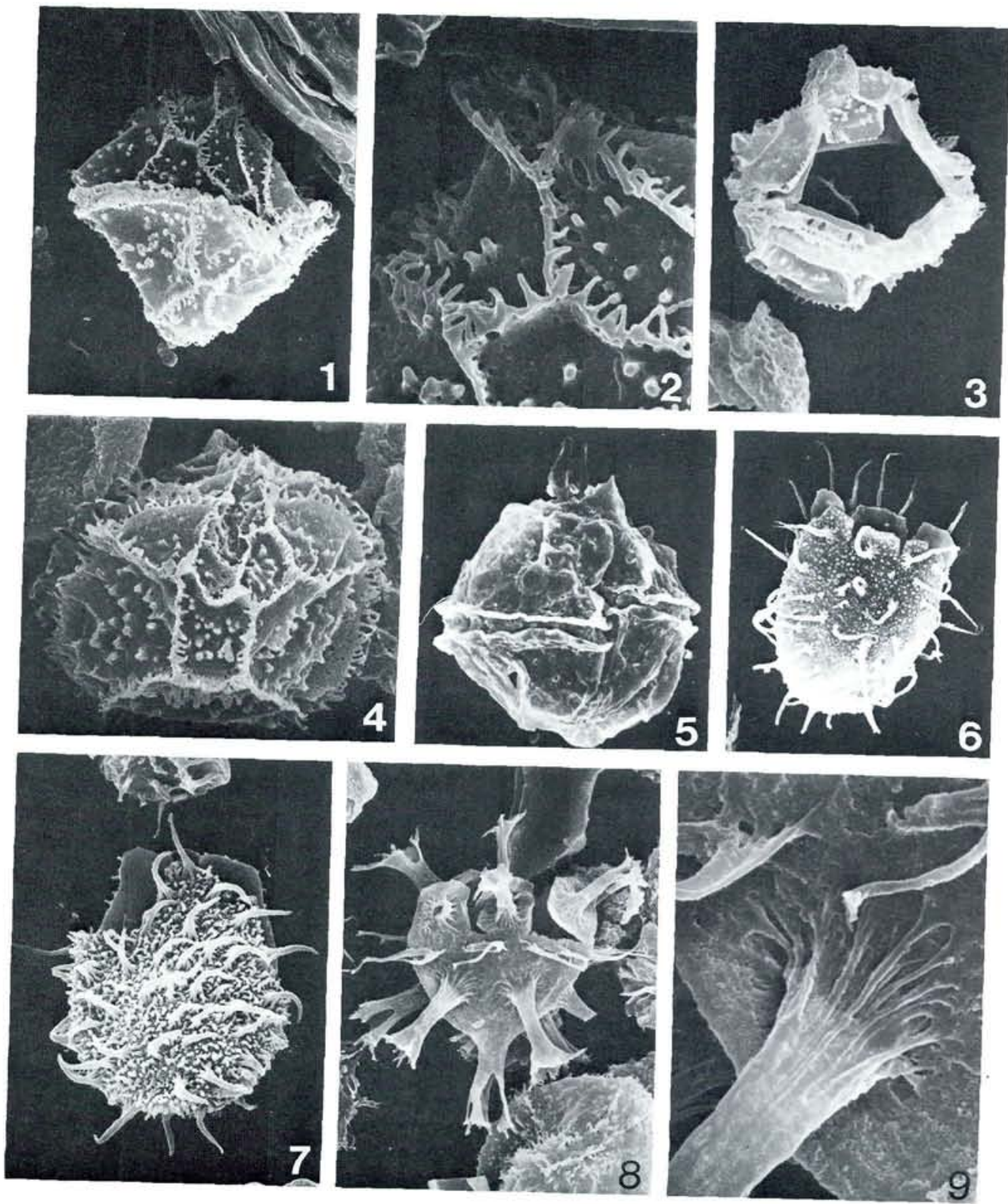
Plate 5.

Figs. 1 \& 9. Chytroeisphaeridia chytroeides Fig. 1 MGUH 17051, specimen with operculum inside (x500), Fig. 9 MGUH 17052 (x800) Figs. 2 \& 10. Escharisphareidia pocockii Fig. 2 MGUH 17053 (x500), Fig. 10 MGUH 17054 (x800)

Figs. 3 \& 11. Sentusidinium brevispinosum Fig. 3 MGUH 17055 (x500), Fig. 11 MGUH 17056 (x600)

Figs. 4 \& 12. Sentusidinium rioultii Fig. 4 MGUH 17057 (x500), Fig. 12 MGUH 17058 (x700)

Fig. 5. Sentusidinium sparsibarbatum MGUH 17059 (x500)

Fig. 6. Sentusidinium neophytensum MGUH 17060 (x500)

Fig. 7. Stephanelytron scarburghense MGUH 17061 specimen showing the corona (x500)

Fig. 8, 13 \& 14. Systematophora sp. Fig. 8 MGUH 17062 (x500), Figs. 13 \& 14 MGUH 17063, Fig. 13 ventral view (x500), Fig. 14 close-up showing the processes $(\mathrm{x} 1200)$

Figs. 9-14. SEM photographs 


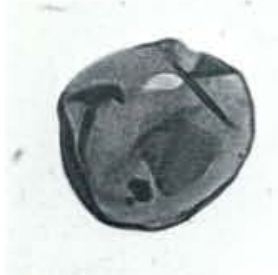

1

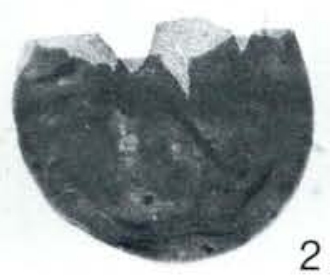

2
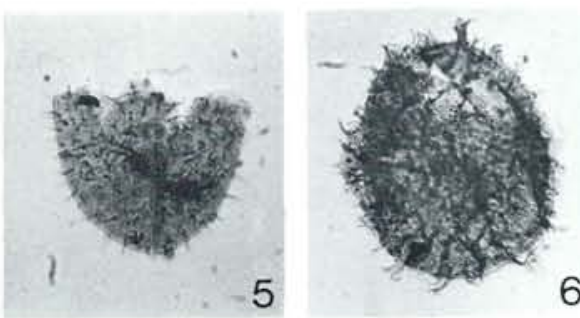

6
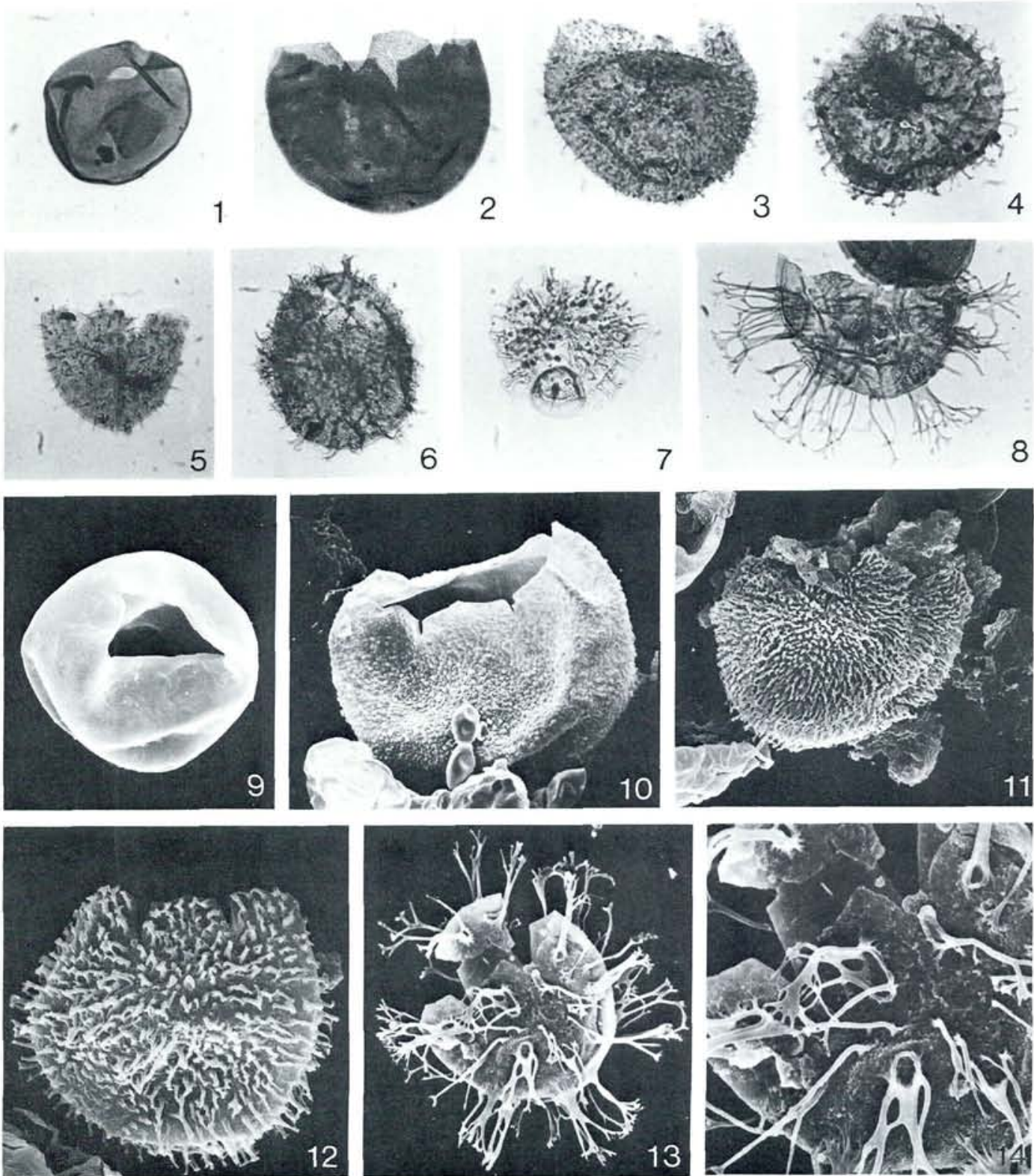